\title{
HISTORI PIAGAM JAKARTA: SPIRIT PERJUANGAN PENERAPAN NILAI ISLAM SECARA YURIDIS KONSTITUSIONAL
}

\author{
Ariesman \\ Sekolah Tinggi Ilmu Islam dan Bahasa Arab (STIBA) Makassar \\ Email: ariesman@stiba.ac.id \\ Iskandar \\ Sekolah Tinggi Ilmu Islam dan Bahasa Arab (STIBA) Makassar \\ Email: iskandarkato@stiba.ac.id
}

\begin{tabular}{ll}
\hline Keywords : & \multicolumn{1}{c}{ ABSTRACT } \\
History, Charter, Jakarta, & The historical journey of Indonesian independence which has long \\
Independence, & been aspired by the nation's generation continues to be fought for, the \\
& role of Islamic figures and Islamic values in coloring all aspects of \\
& community life in the archipelago between a strong foundation to be \\
& free from colonialism, because basically Islam is freedom from \\
& colonialism to beings to worship to the Creator. The process of \\
& Indonesian independence took place in several phases including \\
& Japan's victory over the Netherlands, the phase of the formation of \\
& the BPUPKI team, PPKI, to the process of proclamation of \\
& independence which resulted in the basis of the Indonesian State \\
& known as the "Jakarta Charter" \\
\hline Kata kunci : & \multicolumn{1}{c}{ ABSTRAK } \\
Kejarah, Piagam, Jakarta, & Perjalanan sejarah kemerdekaan bangsa Indonesia yang sejak lama \\
& dicita-citakan oleh generasi bangsa terus diperjuangkan, peranan \\
& tokoh Islam dan nilai-nilai Islam dalam mewarnai semua sisi \\
kehidupan masyarakat di Nusantara di antara dasar yang kuat untuk \\
bebas dari penjajahan, karena pada dasarnya Islam adalah kebebasan \\
dari penjajahan kepada makhluk menuju pemyembahan kepada Sang \\
Pencipta. Proses kemerdekaan Indonesia terjadi beberapa fase di \\
antaranya fase kemenangan Jepang terhadap Belanda, fase \\
terbentuknya tim BPUPKI, PPKI, hingga proses proklamasi \\
kemerdekaan yang menghasilkan dasar Negara Indonesia yang di \\
kenal dengan "Piagam Jakarta".
\end{tabular}




\section{PENDAHULUAN}

Perjuangan generasi bangsa Indonesia untuk merdeka merupakan cita-cita yang terus menjadi harapan agar bisa terwujud. Penindasan yang terus terjadi, kezaliman yang merajalela, perampasan hak dari pihak yang ingin terus menguasai sumber daya alam Indonesia yang kaya raya, adalah merupakan alasan yang kuat agar dapat keluar dari penjajahan tersebut. ${ }^{1}$ Peran umat Islam yang juga merupakan generasi inti dari bangsa Indonesia telah memberikan pengaruh dan kekuatan yang besar untuk terus melakukan upaya pendidikan untuk mewujudkan manusia yang beradab, terus berkembangnya pusat pendidikan, sekolah, pesantren, atau wadah untuk menyebarkan kebaikan hampir merata di seluruh wilayah Indonesia yang nanti akan menjadi spirit perjuangan untuk melawan penjajah. ${ }^{2}$

Pada tanggal 22 Jun 1945, para tokoh perjuangan kemerdekaan Indonesia yang terdiri daripada berbagai latar belakang golongan dan agama, telah melaksanakan suatu "kontrak sosial" yang menyepakati bahwa Negara Indonesia yang akan diproklamirkan kemerdekaannya dan yang akan dibangun kelak adalah bukan negara Agama dan bukan pula negara sekuler, melainkan suatu Negara Kesatuan yang "Berdasarkan Ketuhanan dengan kewajiban menjalankan syariat Islam bagi pemeluknya. Konsensus Nasional tersebut telah dicapai dan ditandatangani oleh para Founding Father Negara Indonesia dalam sebuah piagam yang disebut Piagam Jakarta 22 Juni 1945. ${ }^{3}$ Piagam Jakarta 22 Jun 1945 menjadi pelopor sejarah, sekaligus menjadi pintu gerbang bagi penerapan nilai-nilai Islam di Indonesia secara perlembagaan (yuridis konstitusional) yang berlaku di Negara Kesatuan Republik Indonesia. ${ }^{4}$

Piagam Jakarta (Djakarta Charter) tertanggal 22 Juni 1945 adalah produk kompromi antara golongan Kebangsaan (Nasionalis) dan golongan Islam yang terlibat dalam penyusunan UUD 1945 di BPUPKI. Piagam Jakarta itu sendiri merupakan rancangan Preamble UUD dan Pernyataan Kemerdekaan Negara Indonesia. Yang dimaksud dengan kompromi dalam Piagam Jakarta itu berupa rumusan pada alinea ke-4 yang berbunyi: "Ketuhanan, dengan kewajiban menjalankan syariat Islam bagi pemeluk-pemeluknya". ${ }^{5}$

Hal itu menunjukkan Piagam Jakarta merupakan hasil kesepakatan bersama tanpa adanya perbedaan pendapat. Secara yuridis Piagam Jakarta

\footnotetext{
${ }^{1}$ Muhammad Fauzi, 'Konsep Negara Dalam Perspektif Piagam Madinah Dan Piagam Jakarta', Al-Mawarid, 13.0 (2005),h. 85-101.

${ }^{2}$ Fauzi. Muhammad Fauzi, 'Konsep Negara Dalam Perspektif Piagam Madinah Dan Piagam Jakarta. h.94.

${ }^{3}$ Al-Habib Muhammad Rizieq bin Husain Shihab, 'Pengaruh Pancasila Terhadap Penerapan Syariah Islam Di Indonesia', Disertasi .Universiti Malaya - Kuala lumpur 2012,h.2. Indonesia.h.2.

${ }^{4}$ Al-Habib Muhammad Rizieq bin Husain Shihab, 'Pengaruh Pancasila Terhadap Penerapan Syariah Islam Di

${ }^{5}$ Aidul Fitriciada Azhari, 'KEDUDUKAN PIAGAMAN JAKARTA: Tinjauan Hukum Ketatanegaraan', Profetika, Jurnal Studi Islam, 1 (2007), 94
} 
BUSTANUL FUQAHA: Jurnal Bidang Hukum Islam

Vol. 1, No. 3 (2020) : Hal. 458-471

Website: https://journal.stiba.ac.id

mengandung pengakuan akan keistimewaan umat Islam sebagai penduduk mayoritas di Indonesia sekaligus pengakuan akan berlakunya hukum Islam sebagai sistem hukum positif di Indonesia. Selain itu, yang terpenting adalah kewajiban bagi umat Islam untuk menjalankan syariat Islam yang mengandung perintah konstitusi bagi negara untuk menegakan syariat Islam di kalangan para pemeluk Islam di Indonesia. ${ }^{6}$

\section{PEMBAHASAN}

\section{Pendudukan Jepang di Indonesia}

Pada saat menjelang era 1940-an, kekuatan militer Jepang di Asia dan kebangkitan Hitler di Jerman mengubah situasi politik di Indonesia. Ketika Hitler menyerbu negeri Belanda pada musim semi di tahun 1940-an, rezim kolonial di Indonesia mengeluarkan peringatan siaga penuh. Adanya info Jepang akan masuk ke Indonesia dianggap hal yang strategis untuk melawan Belanda adalah langkah politik yang diperlukan. Namun, Belanda segera bereaksi, mereka menangkapi pemimpin nasional, termasuk tokoh Islam penting seperti Hadji Rasul. ${ }^{7}$

Upaya pendudukan Jepang di Indonesia dengan berlangsungnya perang dunia kedua di kawasan Asia Pasifik (1941-1945), saat itu Jepang berambisi untuk menguasai negara-negara Asia dan merebutnya dari negara-negara imperalis barat. Tujuannya, selain untuk kepentingan supremasi (keunggulan dan kekuasaan) Jepang juga menjadikan daerah-daerah di Asia sebagai tempat menanamkan modal, serta memasarkan hasil industrinya. Sejak awal abad 20 Jepang telah menjadi negara industri dan mulai melaksanakan imperialisme modern, saat itu Jepang berhasil menduduki Korea dan Cina.

Ketika Jepang menduduki Indonesia, pada juli 1941 AS tidak menyetujui tindakan tersebut. Tindakan protes AS dilakukan dengan menghentikan penjualan karet, baja lempengan, minyak bumi dan lain-lain yang sangat dibutuhkan oleh Jepang. Jepang memutuskan untuk menyerang daerah-daerah koloni eropa di Asia Tenggara tujuannya untuk memperoleh barang-barang kebutuhan perang. Dengan itu, Jepang yakin bahwa serangan tersebut dapat menimbulkan perang dengan Amerika Serikat (AS). Jepang mendahului serangan terhadap Pearl Habour, Hawaii. Pada 7-12-1941 setelah menghancurkan Pearl Harbour, Jepang meneruskan serangan ke Filipina pada 10 Desember 1941 dan berhasil menduduki Luzon dan Batoon, lalu pada tanggal 16 Desember berhasil menduduki Burma. Jepang diuntungkan dengan serangan Hitler ke negeri Belanda, sehingga kekuatan

${ }^{6}$ Azhari. Aidul Fitriciada Azhari, 'KEDUDUKAN PIAGAMAN JAKARTA: Tinjauan Hukum Ketatanegaraan ${ }^{7}$ Luthfi Assyaukanie, Ideologi Islam Dan Utopia: Tiga Model Negara Demokrasi Di Indonesia, ke-1 (Jakarta: FREEDOM INSTITUTE, 2011).h.77. 
Belanda terbagi, hal ini menjadi langka awal Jepang bisa menguasai Indonesia dari tangan Belanda. Akhirnya pada 11 januari Jepang mendarat di Indonesia yaitu dirasakan Kalimantan Timur dan berhasil menduduki pulau Kalimantan. Dari Kalimantan, Jepang meneruskan serangannya ke Jawa sebagai pusat bertahan Belanda, dan mulai menduduki daerah-daerah lainnya. Peristiwa perang Asia Pasifik antara tentara sekutu dengan Jepang tersebut mendatangkan berkah bagi perjuangan kemerdekaan Indonesia.

Dengan adanya serangan dadakan dari pihak Jepang itulah yang menyebabkan penyerahan tanpa syarat oleh Letnan Jenderal H. Terpoorten, Panglima Angkatan Perang Hindia Belanda atas nama Angkutan Perang Serikat di Indonesia kepada tentara ekspedisi Jepang di bawah Pimpinan Letnan Jenderal Hitoshi Imamura pada tanggal 8 Maret 1942, sehingga berakhirlah pemerintahan Hindia Belanda di Indonesia, dan dengan resmi mulailah kekuatan pendudukan Jepang di Indonesia.

Pada tanggal 8 Maret 1942, di mana militer Jepang telah berhasil menaklukkan Belanda, mulailah mereka melanjutkan politik yang pernah dijalankan oleh Belanda. Niponisasi mulai diterapkan di hampir seluruh wilayah pendudukan Jepang di Indonesia. Berbeda dengan Belanda, pemerintah Jepang mengadakan perubahan politik yang baru berupa "devide and rule", pecah belah untuk dikuasai. Oleh sebab itu, pihak Jepang sangat faham betul tentang peta kekuatan politik yang sedang berkembang saat itu. Di mana dalam pandangan politiknya, di Indonesia sedang ada dua kekuatan yang sedang bertarung dalam menentukan masa depan negerinya, yaitu nasionalis Islam dan nasionalis yang non Islam. ${ }^{8}$

Pembaharuan di segala bidang dilakukan oleh Jepang dalam awal penjajahannya. Hal ini dilakukan oleh Jepang karena di Indonesia telah menggema rasa nasionalisme untuk keluar dari belenggu penjajahan, yang jika dicegahnya akan mengadakan perlawanan. Dengan demikian, inilah yang tidak diinginkan oleh Jepang setelah belajar banyak dari bagaimana Belanda menjalankan kolonialismenya di Indonesia. Dengan diadakannya pembaharuan tersebut untuk meyakinkan kepada masyarakat Indonesia bahwa kehadiran mereka adalah sebagai saudara tua dalam pengertian politik yang nantinya akan memberikan kemerdekaan Indonesia.

Ketika situasi perang Asia Pasifik mulai memburuk bagi pihak Jepang, apalagi dengan adanya pemboman dari pihak sekutu ke daerah Jepang, yaitu di Hiroshima dan Nagasaki. Akhirnya untuk lebih memanfaatkan para politikus Indonesia dalam mendukung usaha-usaha perjuangannya, mereka kemudian

${ }^{8} \mathrm{Al}$ Chaidar, 'Pengantar Pemikiran Politik Proklamator NII SM Kartosoewirjo Mengungkap Manipulasi Sejarah Darul Islam/DI-TII Semasa Orde Lama Dan Orde Baru’, 1999.h.94. 
bersedia untuk memberi konsesi (kepemilikan) yang lebih besar bagi rakyat Indonesia dari yang pernah dilakukan oleh Belanda sebelumnya. Orang Indonesia kini diperkenankan membentuk organisasi bersenjata sendiri. Pertama, pada bulan Oktober 1943, terbentuknya PETA (Pembela Tanah Air) dan kemudian pada akhir 1944 dibentuklah Hizbullah (Tentara Allah), cabang bersenjata Masyumi Islam.

Pada akhir bulan Juli, para pemimpin Sekutu di Postdam mengeluarkan suatu tuntutan agar Jepang menyerah tanpa syarat. Jepang tidak dapat lagi memikirkan tentang kemenangan ataupun tindakan mempertahankan wilayahwilayah pendudukannya. Tujuannya di Indonesia kini adalah membentuk sebuah negara yang merdeka dalam rangka mencegah berkuasanya kembali lawan, yaitu Belanda. Pada akhir bulan Juli angkatan darat dan angkatan laut Jepang mengadakan suatu pertemuan di Singapura guna merencanakan pengalihan politik dan perekonomian ke tangan bangsa Indonesia. Mereka memutuskan bahwa Jawa akan diberi kemerdekaan pada awal bulan September, sedangkan daerah-daerah lainnya segera menyusul. Janji Jepang untuk sebuah kemerdekaan bangsa Indonesia diwujudkannya dengan mendirikan Dokuritsu Jumbi Chosakai, yaitu "Badan Penyelidik Usaha Persiapan Kemerdekaan Indonesia" (BPUPKI), yang yang dibentuk pada tanggal 29 April 1945. Badan ini dilantik pada tanggal $28 \mathrm{Mei}$ 1945, dengan tempat tugas di Gedung Pejambon-Jakarta, dengan anggota berjumlah 62 orang yang diketuai oleh Dr. Radjiman Wedyodiningrat.

Sejak saat itulah perumusan dasar Negara mulai disusun dan dirumuskan hingga saat nya nanti keluar rumusan yang menjadi kesepakatan bersama nantinya akan dibacakan saat penyataan kemerdekaan Indonesia, bahkan akan menjadi landasan dalam menjalankan pemerintahan di Indonesia.

\section{Perumusan dan Penetapan Piagam Jakarta}

Pada tanggal 28 Mei 1945, diadakan upacara pelantikan dan sekaligus seremonial pembukaan masa persidangan BPUPKI, badan tersebut menggelar dua kali sidang. Sidang Pertama dari tanggal 29 Mei s/d 1 Jun 1945, dan Sidang Kedua dari tanggal $10 \mathrm{~s} / \mathrm{d} 16$ Juli 1945. Keesokan setelah pelantikan barulah dimulai sidang pertama dari tanggal 29 Mei s/d 1 Juni 1945 selama empat hari dengan tujuan untuk membahas bentuk negara Indonesia, filsafat negara "Indonesia Merdeka" serta merumuskan dasar negara Indonesia. Sebelumnya agenda sidang diawali dengan membahas pandangan mengenai bentuk negara Indonesia, yakni disepakati berbentuk "Negara Kesatuan Republik Indonesia" (NKRI), kemudian agenda sidang dilanjutkan dengan merumuskan konstitusi Negara Kesatuan Republik Indonesia. Untuk hal ini, BPUPKI harus merumuskan dasar negara Republik Indonesia terlebih dahulu yang akan menjiwai isi dari Undang-Undang Dasar Negara Kesatuan Republik Indonesia itu sendiri, sebab Undang-Undang Dasar adalah merupakan konstitusi Negara Kesatuan Republik Indonesia. 
Guna mendapatkan rumusan dasar negara Republik Indonesia yang benarbenar tepat, maka agenda acara dalam masa persidangan BPUPKI yang pertama ini adalah mendengarkan pidato dari tiga orang tokoh utama pergerakan nasional Indonesia, yang mengajukan pendapatnya tentang dasar negara Republik Indonesia itu adalah sebagai berikut:

Muh. Yamin pada 29 Mei 1945 menyebutkan bahawa Dasar Negara ada lima, yaitu: 1. Peri Kebangsaan; 2. Peri Kemanusiaan; 3. Peri Ketuhanan; 4. Peri Kerakyatan; 5. Kesejahteraan Sosial. ${ }^{9}$

Soepomo dengan pidatonya di depan sidang pada 31 Mei 1945, yang isinya menyebut tentang Panca Dharma: 1. Persatuan; 2. Kekeluargaan; 3. Keseimbangan Lahir Batin, 4. Musyawarah, 5. Keadilan rakyat.

Soekarno dengan usulannya pada 1 Jun 1945 menyebutkan bahwa Dasar Negara ada lima, yaitu: 1. Kebangsaan Indonesia; 2. Internasionalisme atau Perikemanusiaan; 3. Mufakat atau Demokrasi; 4. Kesejahteraan Sosial; 5. Ketuhanan. ${ }^{10}$

Hal ini di pertegas oleh seorang sejarawan dari kalangan ABRI (Angkatan Bersenjata Republik Indonesia), Prof. Dr. Nugroho Notosusanto pernah mengajukan tesis dengan kesimpulan bahwasanya pencetus Pancasila tidak hanya Ir. Soekarno, melainkan juga Prof. Mr. Muhammad Yamin dan Soepomo. ${ }^{11}$

Berdasarkan fakta dan data yang terungkap di atas, maka diketahui bahwa secara substantif, Prof. Mr. Yamin adalah orang pertama yang mengurai isi kandungan Pancasila dengan istilah Lima Dasar Negara, walaupun beliau tidak menyebut secara jelas istilah Pancasila. Sedangkan secara formalistis, Ir. Soekarno adalah orang yang pertama kali menyebut secara jelas istilah Pancasila sebagai Dasar Negara. ${ }^{12}$

Setelah itu, BPUPKI mengalami masa reses persidangan (periode jeda atau istirahat) selama satu bulan lebih. Sebelum dimulainya masa reses persidangan, dibentuklah suatu panitia kecil yang beranggotakan 9 orang, yang dinamakan "Panitia Sembilan" dengan diketuai oleh Ir. Soekarno, yang bertugas untuk mengolah usul dari konsep para anggota BPUPKI mengenai dasar negara Republik Indonesia dan mencari penyelesaian penyelesaian terbaik dari berbagai pertikaian sikap dan pendapat yang terjadi sepanjang Sidang Pertama BPUPKI. Kesembilan-

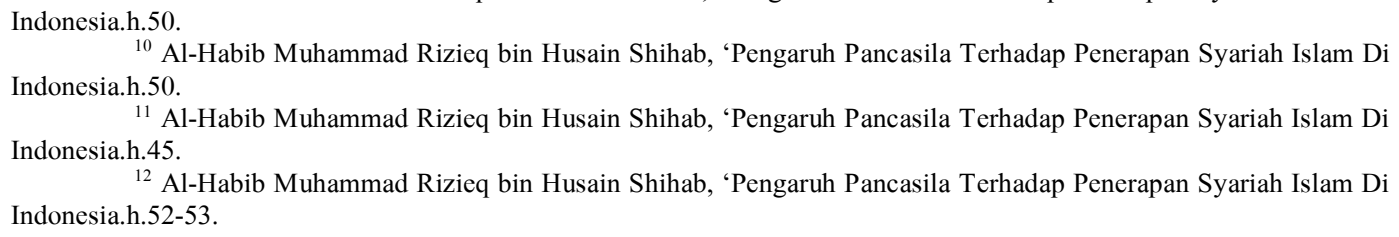

${ }^{10}$ Al-Habib Muhammad Rizieq bin Husain Shihab, 'Pengaruh Pancasila Terhadap Penerapan Syariah Islam Di Indonesia.h.50.

${ }^{11}$ Al-Habib Muhammad Rizieq bin Husain Shihab, 'Pengaruh Pancasila Terhadap Penerapan Syariah Islam Di Indonesia.h.45.

${ }^{12}$ Al-Habib Muhammad Rizieq bin Husain Shihab, 'Pengaruh Pancasila Terhadap Penerapan Syariah Islam Di Indonesia.h.52-53.

Al-Habib Muhammad Rizieq bin Husain Shihab, 'Pengaruh Pancasila Terhadap Penerapan Syariah Islam Di 
BUSTANUL FUQAHA: Jurnal Bidang Hukum Islam

Vol. 1, No. 3 (2020) : Hal. 458-471

Website: https://journal.stiba.ac.id

sembilan anggota Panitia Kecil tersebut terdiri dari kelompok Islam dan kelompok Kebangsaan, mereka di antaranya adalah: ${ }^{13}$

Tabel 1.1. Panitia Sembilan.

\begin{tabular}{lll}
\hline 1 & KH. A. Wahid Hasyim & Nasionalis Islami dari Nahdhotul Ulama (NU). \\
\hline 2 & Haji Agus Salim & Nasionalis Islami dari Syarikat Islam (SI). \\
\hline 3 & Abikoesno Tjokrosoejoso & Nasionalis Islami dari Syarikat Islam (SI) \\
\hline 4 & Abdul Kahar Muzakkir & Nasionalis Islami dari Muhammadiyyah \\
\hline 5 & Soekarno & Nasionalis muslim sekuler. \\
\hline 6 & Muhammad Hatta & Nasionalis muslim sekuler. \\
\hline 7 & Muhammad Yamin & Nasionalis muslim sekuler. \\
\hline 8 & Ahmad Soebardjo & Nasionalis muslim sekuler. \\
\hline 9 & A. A. Maramis & Nasionalis kristian sekuler. \\
\hline
\end{tabular}

Setelah melalui sidang-sidang alot dan perdebatan sengit, akhirnya Panitia Kecil yang disebut juga Panitia Sembilan, melahirkan suatu kesepakatan antara kelompok Islam dan kelompok Kebangsaan. Kesepakatan tersebut ditandatangani oleh seluruh anggota Panitia Sembilan pada 22 Jun 1945, dan dituliskan dalam suatu piagam yang disebut oleh Mr. Muhammad Yamin dengan nama The Djakarta Charter, dan diistilahkan oleh Sukiman dengan nama Gentleman's Agreement. Kini lebih dikenal dengan nama Piagam Jakarta. Selanjutnya, Piagam Jakarta tersebut melalu Sidang Kedua BPUPKI yang dilaksanakan dari 10 s/d 16 Juli 1945, diterima oleh seluruh anggota BPUPKI, bahkan disepakati untuk dijadikan sebagai Preumbul (Pembukaan) Undang-Undang Dasar 1945 atau Pernyataan Kemerdekaan Indonesia. ${ }^{14}$ Adapun agenda lain yang dibahas yaitu tentang wilayah Negara Kesatuan Republik Indonesia, kewarganegaraan Indonesia, rancangan Undang-Undang Dasar, ekonomi dan keuangan, pembelaan negara, serta pendidikan dan pengajaran. ${ }^{15}$

Isi kandungan Piagam Jakarta 22 Juni 1945 sebagaimana berikut: ${ }^{16}$

Bahwa sesungguhnya kemerdekaan itu ialah hak segala bangsa, dan oleh sebab itu maka penjajahan di atas dunia mesti dihapuskan, karena tidak sesuai dengan perikemanusiaan dan perikeadilan.

${ }^{13}$ Al-Habib Muhammad Rizieq bin Husain Shihab, 'Pengaruh Pancasila Terhadap Penerapan Syariah Islam Di Indonesia.h.63-64.

${ }^{14}$ Al-Habib Muhammad Rizieq bin Husain Shihab, 'Pengaruh Pancasila Terhadap Penerapan Syariah Islam Di Indonesia.h.64.

${ }^{15}$ Badan Penyelidik Usaha-Usaha Persiapan Kemerdekaan Indonesia - Wikipedia Bahasa Indonesia, Ensiklopedia Bebas'. di akses 31 Juli 2020.

${ }^{16}$ Al-Habib Muhammad Rizieq bin Husain Shihab, 'Pengaruh Pancasila Terhadap Penerapan Syariah Islam Di Indonesia.h.64-65. 
BUSTANUL FUQAHA: Jurnal Bidang Hukum Islam

Vol. 1, No. 3 (2020) : Hal. 458-471

Website: https://journal.stiba.ac.id

Dan perjuangan pergerakan kemerdekaan Indonesia telah sampailah kepada saat yang berbahagia, dengan selamat sentosa membawa rakyat Indonesia ke depan pintu gerbang Negara Indonesia, yang merdeka, bersatu, berdaulat, adil dan makmur.

Atas berkat rahmat Allah Yang Maha Kuasa, dan dengan didorongkan oleh keinginan luhur, usaha berkehidupan kebangsaan yang bebas, maka rakyat Indonesia menyatakan dengan ini kemerdekaannya.

Kemudian daripada itu untuk membentuk suatu pemerintah Negara Indonesia Merdeka yang melindungi segenap bangsa Indonesia dan seluruh tumpah darah Indonesia, dan untuk memajukan kesejahteraan umum, mencerdaskan kehidupan bangsa, dan ikut melaksanakan ketertiban dunia yang berdasarkan kemerdekaan, perdamaian abadi dan keadilan sosial, maka disusunlah kemerdekaan kebangsaan Indonesia itu dalam suatu susunan negara Republik Indonesia, yang berkedaulatan rakyat, dengan berdasarkan kepada: Ketuhanan dengan kewajiban menjalankan Syariat Islam bagi pemeluk-pemeluknya, menurut dasar kemanusiaan yang adil dan beradab, persatuan Indonesia, dan kerakyatan yang dipimpin oleh hikmat kebijaksanaan dalam permusyawaratan-perwakilan serta dengan mewujudkan suatu keadilan sosial bagi seluruh rakyat Indonesia.

Inilah Rumusan Piagam Jakarta yang menjadi keputusan rasmi Sidang Kedua BPUPKI yang dilaksanakan dari 10 s/d 16 Julai 1945, dan diterima secara aklamasi oleh seluruh anggota BPUPKI, bahkan disepakati untuk dijadikan sebagai Preumbul (Pembukaan) Undang-Undang Dasar 1945 atau Pernyataan Kemerdekaan Indonesia. Rumusan Piagam Jakarta tersebut bukan saja sebagai keputusan resmi Sidang Kedua BPUPKI, tapi juga merupakan Konsensus Nasional yang disepakati oleh para Founding Father Negara Indonesia, inilah Rumusan Piagam Jakarta yang paling tulen. ${ }^{17}$

Konsep proklamasi kemerdekaan negara Indonesia baru rencananya akan disusun dengan mengambil tiga alenia pertama "Piagam Jakarta", sedangkan konsep Undang-Undang Dasar hampir seluruhnya diambil dari alinea keempat "Piagam Jakarta". Sementara itu, perdebatan terus berlanjut di antara peserta sidang BPUPKI mengenai penerapan aturan Islam, Syariat Islam, dalam negara Indonesia baru. "Piagam Jakarta" atau "Jakarta Charter" pada akhirnya disetujui untuk dibacakan saat proklamasi kemerdekaan. ${ }^{18}$

Pada tanggal 7 Agustus 1945, BPUPKI dibubarkan karena dianggap telah dapat menyelesaikan tugasnya dengan baik, yaitu menyusun rancangan UndangUndang Dasar bagi negara Indonesia Merdeka, dan digantikan dengan dibentuknya

${ }^{17}$ Al-Habib Muhammad Rizieq bin Husain Shihab, 'Pengaruh Pancasila Terhadap Penerapan Syariah Islam Di Indonesia.h.66.

${ }^{18}$ Badan Penyelidik Usaha-Usaha Persiapan Kemerdekaan Indonesia - Wikipedia Bahasa Indonesia, Ensiklopedia Bebas'. di akses 31 Juli 2020 
BUSTANUL FUQAHA: Jurnal Bidang Hukum Islam

Vol. 1, No. 3 (2020) : Hal. 458-471

Website: https://journal.stiba.ac.id

"Panitia Persiapan Kemerdekaan Indonesia" ("PPKI") atau dalam bahasa Jepang: Dokuritsu Junbi Inkai dengan Ir. Soekarno sebagai ketuanya. ${ }^{19}$

Tugas "PPKI" ini yang pertama adalah meresmikan pembukaan (bahasa Belanda: preambule) serta batang tubuh Undang-Undang Dasar 1945. Tugasnya yang kedua adalah melanjutkan hasil kerja BPUPKI, mempersiapkan pemindahan kekuasaan dari pihak pemerintah pendudukan militer Jepang kepada bangsa Indonesia, dan mempersiapkan segala sesuatu yang menyangkut masalah ketatanegaraan bagi negara Indonesia baru. ${ }^{20}$

Pada tanggal 6 Agustus dan tanggal 9 Agustus AS menjatuhkan bom atom uranium di Hirosima dan Nagasaki hingga menewaskan 90.000-146.000 orang di Hiroshima dan 39.000-80.000 di Nagasaki, kejadian tersebut berdampak pada kelemahan dan kekosongan kekuasan dari pihak jepang hingga desakan kemerdekaan semakin kuat. ${ }^{21}$

\section{Proses Perubahan Piagam Jakarta}

Sehari setelah proklamasi kemerdekaan, Piagam Jakarta yang telah ditandatangani pada tanggal 22 Juni 1945 itu dibicarakan kembali. Perjalanan sejarah telah mengubah hasil gentlemen agreement itu setelah PPKI dalam persidangannya pada tanggal 18 Agustus 1945 mengubah rumusan "tujuh kata" dalam Piagam Jakarta menjadi rumusan "Ketuhanan Yang Maha Esa" seperti yang terdapat dalam Pembukaan UUD 1945 yang dikenal sekarang ini. Perubahan tersebut didesakkan oleh Bung Hatta yang secara "manipulatif" menginformasikan adanya ancaman dari kalangan Kristen di Indonesia Bagian Timur yang disampaikan seorang opsir Jepang yang akan memisahkan diri bila rumusan "tujuh kata" dalam Piagam Jakarta itu tetap dipertahankan. Golongan Islam pada waktu itu dapat menerima perubahan Piagam Jakarta mengingat situasi genting pasca Proklamasi Kemerdekaan 17 Agustus 1945 serta janji yang dikemukakan oleh Bung Karno yang akan membahas kembali setelah Perang Asia Timur Raya selesai atau enam bulan kemudian setelah Proklamasi Kemerdekaan. Selama revolusi kemerdekaan, umat Islam praktis tidak mempersoalkan perubahan Piagam Jakarta itu. Tetapi setelah revolusi selesai dan terbentuk Konstituante yang bertugas menyusun UUD baru, maka umat Islam memiliki kesempatan untuk mempersoalkan kembali Piagam Jakarta. ${ }^{22}$

\footnotetext{
${ }^{19}$ Badan Penyelidik Usaha-Usaha Persiapan Kemerdekaan Indonesia - Wikipedia Bahasa Indonesia, Ensiklopedia Bebas'. di akses 31 Juli 2020

${ }^{20}$ Badan Penyelidik Usaha-Usaha Persiapan Kemerdekaan Indonesia - Wikipedia Bahasa Indonesia, Ensiklopedia Bebas'. di akses 31 Juli 2020

${ }^{21}$ Badan Penyelidik Usaha-Usaha Persiapan Kemerdekaan Indonesia - Wikipedia Bahasa Indonesia, Ensiklopedia Bebas'. di akses 31 Juli 2020

${ }^{22}$ Aidul Fitriciada Azhari, 'KEDUDUKAN PIAGAMAN JAKARTA: Tinjauan Hukum Ketatanegaraan.h.9293.
} 
Mohammad Hatta masuk ke dalam ruang sidang "PPKI" saat tanggal 18 Agustus 1945 dan membacakan empat perubahan dari hasil kesepakatan dan kompromi atas lobi-lobi politik tersebut: ${ }^{23}$

1. Kata "Muqaddimah" diganti dengan kata "Pembukaan";

2. Dalam Preumbul UUD 1945, yang tidak lain dan tidak bukan adalah Piagam Jakarta, anak kalimat: "berdasarkan Ketuhanan dengan kewajiban menjalankan Syariat Islam bagi pemeluk- pemeluknya" diubah menjadi "berdasarkan Ketuhanan Yang Maha Esa";

3. Pasal 6 ayat 1 yang berbunyi: "Presiden ialah orang Indonesia asli dan beragama Islam" diubah menjadi "Presiden ialah orang Indonesia asli";

4. Pasal 29 ayat 1 yang berbunyi: "Negara berdasarkan atas Ketuhanan dengan kewajiban menjalankan Syariat Islam bagi pemeluk-pemeluknya" diubah menjadi "Negara berdasarkan atas Ketuhanan Yang Maha Esa".

Inilah Rumusan Piagam Jakarta yang menjadi keputusan kontroversial Sidang PPKI yang dilaksanakan. Piagam Jakarta yang didapat dengan susah payah, melalui sidang- sidang alot dan perdebatan sengit, dalam suasana musyawarah kekeluargaan yang penuh saling pengertian, lintas sektoral tanpa campurtangan asing, melibatkan berbagai komponen bangsa secara representatif, lahir sebagai Konsensus Nasional antara Pihak Islam dan Pihak Kebangsaan dari segenap Para Penubuh Negara Indonesia, akhirnya diubah melalui suatu proses sidang yang terburu-buru, singkat dan kilat, serta tidak representatif. Karenanya, amat tepat istilah yang dinyatakan Ketua Umum Masyumi, Prawoto Mangkusaswito, bahwasanya peristiwa perubahan Piagam Jakarta tersebut telah melahirkan Historische Vraag yaitu Pertanyaan Sejarah. ${ }^{24}$

Pernyataan Kemerdekaan Republik Indonesia pada 17 Agustus 1945 mengundang kemarahan pemerintah Belanda, karena selepas kekalahan Jepang oleh Tentara Bersekutu, maka pemerintah Belanda merasa paling berhak mengambil alih Indonesia dari tangan pemerintah Jepang. Untuk tujuan mengembalikan kekuasaannya atas Indonesia, Belanda melancarkan dua kali tindakan ketenteraan terhadap Republik Indonesia, pertama pada 21 Juli 1947, dan kedua pada 18 Desember $1948 .^{25}$

Ketika itu keadaan Republik Indonesia kacau balau, karena disamping menghadapi tekanan-tekanan pihak Belanda, masih ditambah dengan pemberontak PKI (Partai Komunis Indonesia) di Surakarta dan Madiun pada September 1948. Pada peristiwa tersebut banyak daerah yang dikuasai oleh Indonesia.h.70.

${ }^{23}$ Al-Habib Muhammad Rizieq bin Husain Shihab, 'Pengaruh Pancasila Terhadap Penerapan Syariah Islam Di

${ }^{24}$ Al-Habib Muhammad Rizieq bin Husain Shihab, 'Pengaruh Pancasila Terhadap Penerapan Syariah Islam Di Indonesia.h,74.

${ }^{25}$ Al-Habib Muhammad Rizieq bin Husain Shihab, 'Pengaruh Pancasila Terhadap Penerapan Syariah Islam Di Indonesia.h.75. 
BUSTANUL FUQAHA: Jurnal Bidang Hukum Islam

Vol. 1, No. 3 (2020) : Hal. 458-471

Website: https://journal.stiba.ac.id

Belanda bahkan para pemimpin Republik Indonesia ditangkap, antara lain: Soekarno, M. Hatta, Syahrir, Agus Salim, dan lainya. Akibatnya, karena Presiden dan wakil Presiden beserta hampir semua anggota kabinet Republik Indonesia ditangkap oleh Belanda, maka dibentuklah Pemerintahan Darurat Republik Indonesia dengan Mr. Syafruddin Prawiranegara sebagai Presidennya. ${ }^{26}$

Tekanan Belanda yang amat kuat berhasil memaksa Republik Indonesia maju ke meja perundingan. Melalui statemen Room, Van Royen pada 7 Mei 1949, Belanda mengembalikan Soekarno-Hatta dan kawan-kawan ke Yogyakarta dari pembuangannya di Bangka. Selanjutnya, Republik Indonesia (RI) dan Bijeenkomst voor Federale Overleg (BFO) ikut serta dalam Konferensi Meja Bundar di Den Haag dari 23 Agustus s/d 2 November 1949 menyepakati terbentuknya Republik Indonesia Serikat (RIS). ${ }^{27}$

Republik Indonesia Serikat (RIS) yang didirikan pada 29 Oktober 1949 melalui Konferensi Meja Bunder, ternyata tidak bertahan lama, bahkan kurang dari setahun. Pada 3 April 1950, M. Natsir dan kawan- kawan di Dewan Perwakilan Rakyat Federal tampil mengajukan usul yang kemudian dikenal dengan Usul Integral Natsir. Pada hari yang sama usul tersebut dikabulkan oleh DPR Federal. Selanjutnya, pada 19 Mei 1950 digelar Konferensi RIS - RI yang menyepakati untuk membentuk Negara Kesatuan Republik Indonesia (NKRI). Pada 20 Juli 1950, disetujui Undang-Undang Dasar Sementara NKRI 1950 yang baru dibuat kuasa pada 14 Agustus $1950 .^{28}$

Sesuai amanat UUDS 1950 bab V pasal 134 yang menyatakan: "Konstituante (Sidang Pembuat Undang-Undang Dasar) bersama-sama dengan Pemerintah selekas-lekasnya menetapkan Undang-Undang Dasar Republik Indonesia yang akan menggantikan Undang-Undang Dasar Sementara ini." Dengan demikian, pada 15 Desember 1955 untuk pertama kalinya digelar Pemilihan Umum untuk membentuk Majelis Konstituante. Selanjutnya, Majelis Konstituante yang terbentuk melakukan sidang-sidang guna membuat UndangUndang Dasar. Dalam proses perumusan Pancasila kali ini, sikap Majelis Konstituante terbelah dua dari Islam dan sekuler. Kenyataan itulah yang mendorong Presiden Soekarno, selaku Panglima Tertinggi Angkatan Perang Republik Indonesia, mengeluarkan Dekrit Presiden 5 Juli 1959, yang isinya sebagai berikut: 29

${ }^{26}$ Al-Habib Muhammad Rizieq bin Husain Shihab, 'Pengaruh Pancasila Terhadap Penerapan Syariah Islam Di Indonesia.h.77.

${ }^{27}$ Al-Habib Muhammad Rizieq bin Husain Shihab, 'Pengaruh Pancasila Terhadap Penerapan Syariah Islam Di Indonesia.h.78.

${ }^{28}$ Al-Habib Muhammad Rizieq bin Husain Shihab, 'Pengaruh Pancasila Terhadap Penerapan Syariah Islam Di Indonesia.h.79-80.

${ }^{29}$ Al-Habib Muhammad Rizieq bin Husain Shihab, 'Pengaruh Pancasila Terhadap Penerapan Syariah Islam Di Indonesia.h. $82-83$ 
BUSTANUL FUQAHA: Jurnal Bidang Hukum Islam

Vol. 1, No. 3 (2020) : Hal. 458-471

Website: https://journal.stiba.ac.id

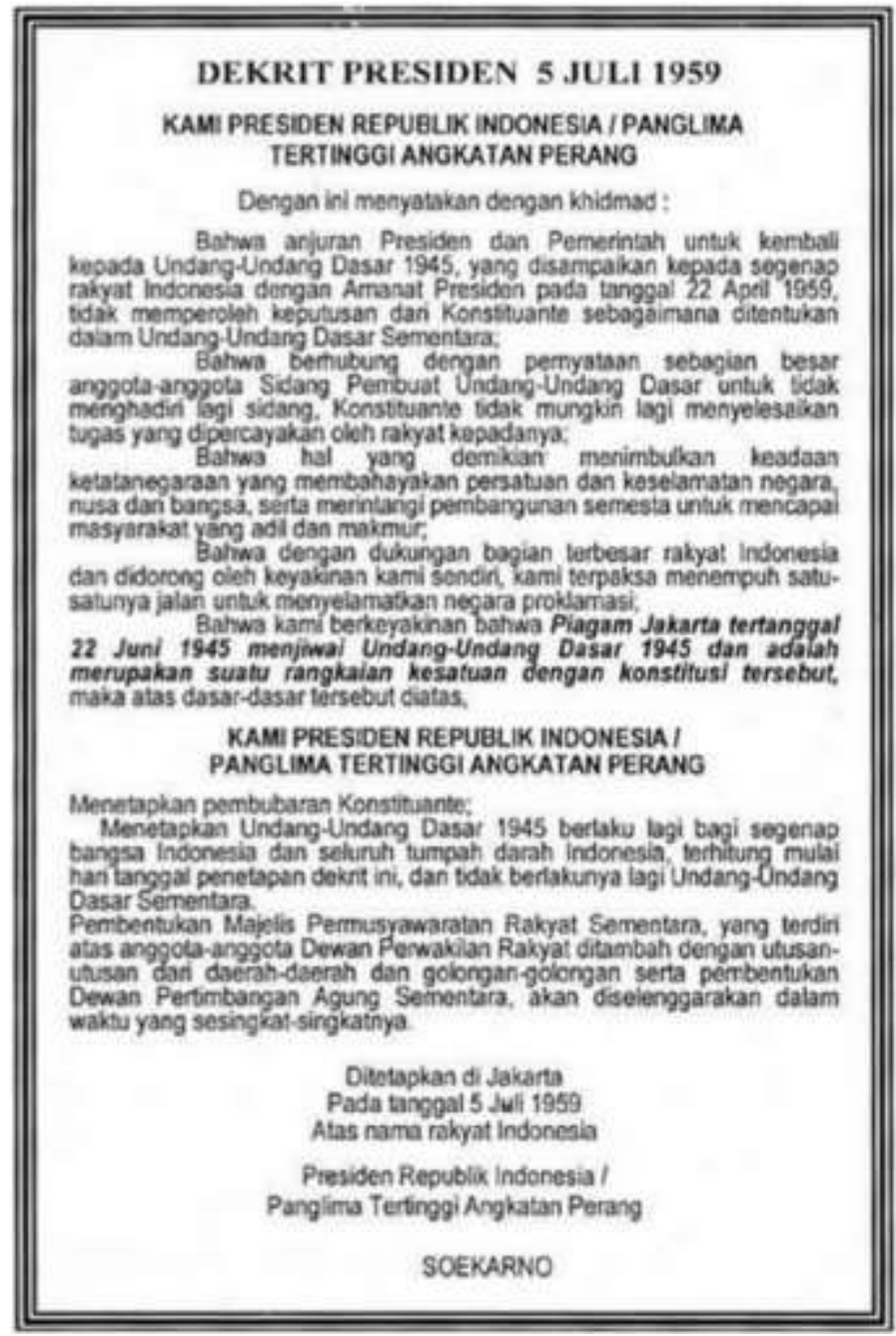

Gambar 1.1. Dekrit Presiden 5 Juli 1959

Sekalipun secara formal Dekrit Presiden 5 Juli 1959 memberlakukan kembali UUD 1945, tetapi secara substansial Dekrit tersebut mengakui berlakunya Piagam Jakarta 22 Juni 1945 sebagai sumber hukum positif di Indonesia. Hal itu ditunjukkan dengan adanya konsideran dalam Dekrit Presiden yang menyatakan: "Kami berkeyakinan bahwa Piagam Jakarta tertanggal 22 Juni 1945 menjiwai UUD 1945 dan adalah merupakan suatu rangkaian kesatuan dengan konstitusi tersebut."

Berdasarkan rumusan Dekrit dan keterangan PM Juanda itu, maka penetapan Piagam Jakarta dalam Dekrit mengandung akibat hukum yang sangat fundamental:

Pertama, secara yuridis Piagam Jakarta merupakan sumber hukum positif di Indonesia. Kalimat "menjiwai UUD 1945 dan adalah merupakan suatu rangkaian kesatuan dengan konstitusi tersebut" tidak dapat ditafsirkan lain kecuali keberadaan UUD 1945 tidak dapat dilepaskan dari Piagam Jakarta. Dengan 
BUSTANUL FUQAHA: Jurnal Bidang Hukum Islam

Vol. 1, No. 3 (2020) : Hal. 458-471

Website: https://journal.stiba.ac.id

demikian, UUD 1945 harus dilaksanakan berdasarkan substansi yang terkandung dalam Piagam Jakarta. Demikian pula seluruh peraturan perundang-undangan nasional secara substansial harus dilaksanakan berdasarkan muatan yang terkandung dalam Piagam Jakarta. ${ }^{30}$

Kedua, karena kedudukan yang bersifat "menjiwai" maka secara teoretis kedudukan Piagam Jakarta itu adalah sebagai Groundnorm. Menurut Hans Kelsen yang dimaksud dengan Groundnorm dalam suatu tatanan hukum positif nasional adalah "the historically first constitution as the highest legal authority." Secara historis Piagam Jakarta lebih tua dibandingkan Proklamasi Kemerdekaan 17 Agustus 1945 dan UUD 1945 yang disahkan pada tanggal 18 Agustus 1945, sehingga dengan kedudukan seperti yang ditetapkan Dekrit Presiden maka Piagam Jakarta adalah "the historically first constitution" yang merupakan Groundnorm bagi tata hukum positif Indonesia. ${ }^{31}$

Piagam Jakarta memiliki kedudukan konstitusional yang kuat karena telah ditetapkan oleh Kepres No. 150 ahun 1959 tentang Dekrit Presiden tertanggal 5 Juli 1959 dan dimuat dalam Lembaran Negara RI No. 75 Tahun 1959 serta diperkuat lagi dengan penetapan MPR-RI tentang Perubahan Keempat UUD 1945 pada tanggal 10 Agustus 2002. Dengan kedudukan konstitusional yang kuat itu, terdapat kewajiban bagi umat Islam dan negara untuk menjalankan syariat Islam di Indonesia sebagaimana dikehendaki oleh Piagam Jakarta. ${ }^{32}$

\section{KESIMPULAN}

Pendudukan Jepang ke Indonesia merupakan langkah awal proses kemerdekaan yang tentunya merupakan karunia dan jalan yang Allah berikan untuk bangsa Indonesia untuk bisa bebas dari cengkraman para penjajah. Perumusan Piagam Jakarta dilakukan dengan diskusi dan musyawarah yang panjang diwarnai dengan perdebatan namun pada akhirnya dapat dikompromikan dan disepakati untuk kemaslahan persatuan dan kebersamaan para tokoh bangsa. Proses perumusan, pengesahan piagam Jakarta bahkan terjadinya beberapa kali perubahan merupakan dinamika yang terjadi dengan kondisi tekanan dengan gejolak munculnya perselisihan dan ancaman hingga akhirnya diambil jalan tengah hingga saat ini piagam Jakarta menjiwai UUD 45.

\section{DAFTAR PUSTAKA}

Assyaukanie, Luthfi. (2011). Ideologi Islam Dan Utopia: Tiga Model Negara Demokrasi Di Indonesia, Cetakan ke-1 Jakarta: FREEDOM INSTITUTE.

\footnotetext{
${ }^{30}$ Aidul Fitriciada Azhari, 'KEDUDUKAN PIAGAMAN JAKARTA: Tinjauan Hukum Ketatanegaraan. h.94.

${ }^{31}$ Aidul Fitriciada Azhari, 'KEDUDUKAN PIAGAMAN JAKART A: Tinjauan Hukum Ketatanegaraan.h.94.

${ }^{32}$ Aidul Fitriciada Azhari, 'KEDUDUKAN PIAGAMAN JAKARTA: Tinjauan Hukum Ketatanegaraan.h.98.
} 
BUSTANUL FUQAHA: Jurnal Bidang Hukum Islam

Vol. 1, No. 3 (2020) : Hal. 458-471

Website: https://journal.stiba.ac.id

Azhari, Aidul Fitriciada. (2007). 'Kedudukan Piagaman Jakarta: Tinjauan Hukum Ketatanegaraan', Profetika, Jurnal Studi Islam, 1.

Badan Penyelidik Usaha-Usaha Persiapan Kemerdekaan Indonesia - Wikipedia Bahasa Indonesia, Ensiklopedia Bebas' https: // id. wikipedia. org / wiki / Badan_Penyelidik_Usaha-usaha_Persiapan__Kemerdekaan_Indonesia Sidang_resmi_pertamā [accessed 31 Juli 2020]

Chaidar, Al,. (1999). 'Pengantar Pemikiran Politik Proklamator NII SM Kartosoewirjo Mengungkap Manipulasi Sejarah Darul Islam/DI-TII Semasa Orde Lama Dan Orde Baru'.

Fauzi, Muhammad. (2005). 'Konsep Negara Dalam Perspektif Piagam Madinah Dan Piagam Jakarta', Al-Mawarid, 13.0.

Shihab, Al-Habib Muhammad Rizieq bin Husain. (2012). 'Pengaruh Pancasila Terhadap Penerapan Syariah Islam Di Indonesia' Disertasi. Universiti Malaya - Kuala lumpur. 